\title{
EUROPEAN CRIMINAL LAW REVIEW
}
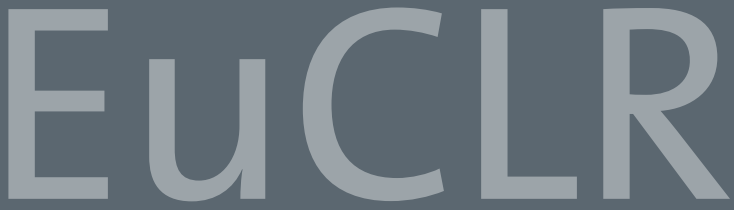

\section{EDITORS}

Prof. Dr. Petter Asp, Stockholm (S)

Prof. Dr. Luigi Foffani, Modena (I)

Prof. Dr. Maria Kaiafa-Gbandi,

Thessaloniki (GR)

Prof. Dr. Helmut Satzger,

Munich (D)

Prof. Dr. Ingeborg Zerbes,

Bremen (D)

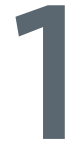

2016

Volume 6

Pages 1- 112

ISSN 2191-7442

\section{EDITORIAL}

\section{ARTICLES}

Anne Schneider

Res Judicata in Criminal Matters and the

European Courts - A Comparison Between

Germany and Italy (Part I)

Georg C. Langheld

Multilingual Norms in European Criminal Law

Lisa F.M. Ansems \& Charlene R.R. Loeve

Targeted Financial Sanctions: Criminal in Nature?

An Analysis of the Case Law of the ECtHR and the

CJEU on the Nature of Targeted

Financial Sanctions

Sofie Depauw

A European Evidence (Air)Space? Taking Cross-Border Legal Admissibility of Forensic Evidence

to a Higher Level

Athina Giannakoula

The European Agenda on Security -

A Comment

\section{Nomos}




\section{EUCLR}

European Criminal Law Review
$1 / 2016$

Volume 6

Page 1-112

Editors: Prof. Dr. Petter Asp; Prof. Dr. Luigi Foffani; Prof. Dr. Maria Kaiafa-Gbandi;

Prof. Dr. Helmut Satzger; Prof. Dr. Ingeborg Zerbes

Editor-in-chief: Prof. Dr. Helmut Satzger

\section{Table of Contents}

Editorial

\section{ArTicles}

Anne Schneider

Res Judicata in Criminal Matters and the European Courts - A Comparison Between

Germany and Italy (Part I)

Georg C. Langheld

Multilingual Norms in European Criminal Law

Lisa F.M. Ansems \& Charlene R.R. Loeve

Targeted Financial Sanctions: Criminal in Nature?

An Analysis of the Case Law of the ECtHR and the CJEU on the Nature of Targeted Financial Sanctions

Sofie Depauw

A European Evidence (Air)Space? Taking Cross-Border Legal Admissibility of Forensic Evidence to a Higher Level

Athina Giannakoula

The European Agenda on Security - A Comment 


\section{EUCLR European Criminal Law Review}

Editor-in-chief: Prof. Dr. Helmut Satzger

Lehrstuhl für Deutsches, Europäisches und

Internationales Strafrecht und Strafprozessrecht sowie Wirtschaftsstrafrecht

Ludwig-Maximilians-Universität

Prof.-Huber-Platz 2

80539 München

Telephone: +49-(0)89 - 21802734

Mail: h.satzger@lmu.de

www.euclr.de

Publication: three times a year

Subscription prices 2016: Annual subscription: incl. online-access (Private subscriber) 158,- $€$, for institutions incl. online-access $229,-€$; Single issues: $57,-€$. Prices do not include postage and packing.

Orders: Subscriptions and orders should be sent to: Nomos Verlagsgesellschaft mbH, D-76520 BadenBaden, Germany.

Cancellation Period: Termination within 3 months notice to the end of the year.

Banking details: payable in advance to Nomos Verlagsgesellschaft, Postbank Karlsruhe: IBAN: DE07 6601007500736367 51, BIC: PBNKDEFF or Sparkasse Baden-Baden Gaggenau: IBAN: DE05 6625003000050022 66, BIC: SOLADES1BAD

Production and Publishing: Nomos Verlagsgesellschaft mbH \& Co. KG, Waldseestr. 3-5, D-76484 Baden-Baden, Telephone (07221) 2104-0/Fax (07221) 2104-27, E-Mail: nomos@nomos.de

Advertisement: Sales friendly Verlagsdienstleistungen, Pfaffenweg 15, 53227 Bonn, Telefon (0228) 978980/Fax (0228) 9789820, E-Mail: roos@salesfriendly.de.

ISSN 2193-5505

\section{Copyright and Right of Publishing:}

The journal and all individual articles and illustrations it contains are protected by copyright. Any re-use that is not expressly granted by copyright law requires the previous consent of the publisher. Upon acceptance of publication, the author transfers to the publisher the following rights with respect to his or her work for the duration of the legal copyright: the exclusive, worldwide and temporally unrestricted right to reproduce and distribute in physical form; the right to public reproduction and public display; the right to inclusion in databases; the right to store on electronic data storage media; the right to distribute and reproduce such storage media; and the right to make other use of the work in electronic form. This final right includes the use of electronic forms that are, at present, unknown. This granting of rights also covers the exploitation of the rights of use both by the Publisher itself as well as through the transfer or the granting (including partially) of rights to third parties.

After the expiry of one year, the author may publish the manuscript version of his or her work elsewhere, according to the requirements set out in $\$ 38$ Para. 1 Sent. 2 and Para. 2 of the Copyright Act. The right to self-archiving on the author's own web site and the web site of the institution where he or she works (cf. $\$ 38$ Para. 4 of the Copyright Act) remains unaffected. Nomos Publishing is a "green publisher." Provided that author's royalties are being paid by the publishing organ, the rights listed under 1 . are to be considered paid for in their entirety by the agreed upon one-time lump sum payment. If a sales-based payment arrangement has been agreed to for the printed version, then the same payment arrangement applies to revenues from electronic utilization. The invoicing takes place at the same interval as for the printed version. For periodicals that are also financed by authors' and publishers' subsidies or by third parties, it may be assumed that the subsidy needs were reduced by a waiver of royalties. Therefore, separate payment claims exist only in the context of new utilization forms and/or when the revenues earned with a known utilization form prove to be significantly above average.

Unsolicited, submitted manuscripts--for which no liability is assumed--are considered proposals for publication according to the terms of the publisher. The editors allow themselves a longer period for examining submissions. No liability is assumed for damage or loss. Only unpublished original works are accepted. The author grants his or her consent to a non-distorting editorial treatment of the submitted work.

Works identified by name do not always reflect the opinions of the anthologist/editor or publisher.We offer no guarantee that unsolicited submitted review pieces will be discussed or returned.

The regulations of the Börsenverein des Deutschen Buchhandels e.V. (German Publishers and Booksellers Association) for the use of book reviews (status 9/2013) apply to the use of review extracts. 